This is the post print version of the article, which has been published in European Sociological Review . 2017, 33 (6), 791-807. http://dx.doi.org/10.1093/esr/jcx077.

\title{
Gender differences in retirement in a welfare state with high female labour market participation and competing exit pathways
}

\section{This document has been downloaded from TamPubuta.fi
The Insitutuonal Repository of University of Tampere}

Aart-Jan Riekhoff

Faculty of Social Sciences,

Kalevantie 5, 33014 University of Tampere, Finland.

E-mail: arie.riekhoff@staff.uta.fi

Noora Järnefelt

Finnish Centre for Pensions,

00065 Eläketurvakeskus, Finland.

E-mail: noora.järnefelt @etk.fi

Acknowledgements: The authors would like to thank Tuula Kyyrä for retrieving the data from the Finnish Centre for Pensions, as well as Liudmila Lipiäinen and Pertti Koistinen for their help in gaining access to FLEED. Gratitude is also due to Olli Kangas for commenting on an earlier draft of the manuscript. 


\title{
Gender differences in retirement in a welfare state with high female labour market participation and competing exit pathways
}

\begin{abstract}
In this article, we analyse whether and how, in the context of high female labour market participation and competing exit pathways, Finnish women's retirement differs from men's. We test for the influence of gendered life courses, social stratification, late career vulnerability and sector. Using data from the Finnish Centre for Pensions, we created individual sequences of monthly income statuses between ages 57 and 65 for a cohort born in $1948(N=55,971)$. Following sequence analysis, we identified eight distinct trajectory clusters that represent the variety of labour market withdrawal through the competing exit pathways. We linked these clusters to a set of sociodemographic background variables from Finnish Longitudinal Employer-Employee Data (FLEED). We find that women's retirement trajectories do not differ substantially from men's, but that the factors affecting the take-up of those trajectories show significant differences. Marital status, education, income and especially public sector employment play a greater role in determining the timing and mode of women's retirement. The findings suggest that women's retirement is different because their marital status, education and income has a stronger effect on their attachment to the labour market and because they work in particular female-dominated occupations.
\end{abstract}




\section{Introduction}

Finland's population is among the most rapidly ageing in Europe, putting its welfare system under considerable pressure (OECD, 2014). Although labour market participation is increasing among older workers, Finland's labour market participation rate of the 55+ population is the lowest among the Nordic countries. In 2015, only 60 per cent of the Finnish population aged 55-64 was employed, compared to 65 per cent in Denmark, 72 per cent in Norway and 75 per cent in Sweden (Eurostat, 2016). Finland is usually classified in the Nordic welfare regime, which is characterised by promoting high labour market participation among older workers in order to sustain generous and universal pension systems (Blossfeld, Buchholz and Hofäcker, 2006). In the 1970s and 1980s, however, Finland's pension schemes were specifically designed to accommodate structural economic change and alleviate unemployment through early exit. Policy-makers are still in the process of addressing this institutional legacy (OECD, 2014).

Finland also stands apart from its Nordic neighbours, and indeed from the rest of Europe, in terms of older women's employment. In 2015 the employment rate in the age group of 55-64 was higher among women (62.5\%) than men (57.4\%) (Eurostat, 2016). This presents a unique background for studying gender differences in retirement behaviour. Because of the more fragmented nature of women's labour market participation, past research has often focused on men's retirement only. Even today, men's retirement is treated as the norm and point of comparison. In this study, we test whether various theoretical explanations for women's divergent retirement patterns hold water against the background of their high rates of labour market participation in Finland. 


\section{Previous research and theory}

\section{Gendered life courses}

The literature offers several explanations as to why women's retirement differs from men's. These explanations are often closely interconnected, but can be grouped into at least four main categories. First, work-family life courses are gendered, and the 'institution of the family' is typically considered to have had a stronger effect on women's than men's careers and retirement (Fasang, 2010; Krüger and Levy, 2001). Women more often bear the responsibility for raising and caring for children, and therefore they have longer career breaks or work part-time. Following the 'status maintenance hypothesis', this leads to lower levels of labour market attachment among women, resulting in earlier exit from paid work. At the same time, shorter careers may mean lower levels of pension accrual. According to the 'compensation hypothesis', this may lead to women, especially in dual earner societies, deferring retirement until it is financially feasible (Finch, 2014; König, 2017). This effect might be stronger for divorced women who (re)enter the labour market after separation (Fasang, Aisenbrey and Schömann, 2013; Finch, 2014). Women's decisions to retire early are more likely to be affected by the retirement of their (older) husbands or by the need to care for grandchildren or ageing family members (Denaeghel, Mortelmans and Borghgraef, 2011; Henkens and Van Solinge, 2002).

Women's labour market participation has been at a high level in Finland for decades, reflecting education, labour market and family policies that have supported the continuity of women's careers over the life course (Järnefelt, 2010). Raising a family is supposed to have had little effect on pension accrual. Even so, women more often end up in lower paid jobs, which is the main reason for a considerable gender pension gap (Rantala and Riihelä, 2016). Nevertheless, little is known about whether the predominance of the dual earner model makes Finnish women less likely to let family reasons affect their retirement behaviour. 


\section{Social stratification}

Differences in retirement might be due to men and women having substantially different socioeconomic positions. Again, the status maintenance and compensation hypotheses may apply here. According to the former, better-educated women in higher occupational positions and with higher income will be more attached to the labour market and retire later. According to the latter, women need to work longer because of their lower-qualified and lower-paid jobs over the life course (Finch, 2014; König, 2017). Radl (2013) found support for a 'primacy of class thesis' in retirement, arguing that differences in retirement between men and women are primarily explained by women having lower occupational statuses, especially in the case of 'involuntary' early exit.

In a study on Norway, a Nordic country with similarly high female employment rates, Dahl, Nilsen and Vaage (2003) found that the effect of higher education on lowering the risk of exit through 'involuntary pathways' was stronger among women than men. Similar effects were found in Finland: the positive effects of higher education on longer working lives and its negative effects on exit through unemployment were especially pronounced for women (Järnefelt, 2010). Moreover, under the Finnish flexible retirement scheme, income has been a factor in postponing exit among women, but less so among men (Tuominen, 2013).

\section{Vulnerability in late careers}

It is possible that because of interrupted careers, part-time work, lower income and insecure employment, women are more vulnerable in their late careers and as a result retire earlier (MaderoCabib, 2015). Studies in the US have found that disruptions in late careers, such as unemployment or long-term sickness, have different effects on men and women, although the direction of these effects remain unclear. Again, there are status maintenance and compensation arguments to illustrate these differences. In accordance with the status maintenance hypothesis, Chan and Stevens (1999) found that men were more likely to become re-employed after job loss in their late careers, 
whereas women had largely lost their incentives to work and retired early. Raymo et al. (2011), on the contrary, found that involuntary job exit and exposure to insecure and low-paid jobs lowered the likelihood of early retirement for both men and women, but that this effect was stronger for women.

It is possible that Finnish women are less vulnerable in their late careers than women in other countries. As argued above, Finnish women are less likely to experience labour market detachment due to family formation. Part-time work is not particularly common in Finland. Older workers have the option of part-time retirement, by working shorter hours and receiving a partial pension. Part-time pensions have been more common among women, but cannot be regarded as a symptom of vulnerability, as their take-up is higher in middle and higher income brackets (Takala and Väänänen, 2016). A recent study by Kurvinen et al. (2016) found that the occurrence of job loss after the age of 45 more often led to early exit through retirement, disability or unemployment pensions for men than for women.

\section{Sectoral differences}

Finally, it is possible that the existence of separate male- and female-dominated sectors leads to institutionally structured differences in retirement patterns (Krüger and Levy, 2001). Sector of employment can affect retirement in various ways (Blossfeld, Buchholz and Hofäcker, 2006; De Preter, Mortelmans and Van Looy, 2012). There are 'declining sectors', such as manufacturing and agriculture, where opportunities for early exit are exploited to a greater extent than in sectors where employment is continuing to expand. There are also sectors that are more vulnerable to economic cycles, while sectoral collective bargaining or a stronger presence of trade unions can reduce vulnerability. In some sectors, work may be more demanding physically or cognitively, creating a need for early exit options. Finally, retirement can be organised differently per sector because of separate legislation or particular occupational pensions. 
As in the other Nordic welfare states, women in Finland dominate employment in public health, social and education sector jobs. These jobs have increased over the past decades and offer relatively stable and secure employment with low risks of unemployment. It has been found that women in these jobs retire later, even though some of these occupations make them eligible for early retirement (Järnefelt, 2010; Tuominen, 2013). Later retirement may be due in part to financial necessity: income is relatively low compared to private sector jobs with similar qualification requirements.

Retirement and exit pathways in the Finnish pension system until 2017

Gender differences in retirement should be seen in their institutional context (Fasang, 2010; König, 2017). Finland has a hybrid pension system, consisting of two main tiers. The predominant tier is the statutory earnings-related pension. Retirement age under the earnings-related scheme is flexible between 63 and 68, with financial incentives to defer retirement. Early retirement on an earningsrelated pension is possible at age 62 , but involves a permanent reduction of benefits. Special pensions in the earnings-related scheme are available for farmers who give up commercial agriculture before the age of 63 (ETK and Kela, 2015). The second tier, the 'national pension' covers all those permanently resident in Finland. It is financed from the state budget and tops up earnings-related pensions to a specified maximum amount. An additional 'guarantee pension' ensures a minimum income level (ETK and Kela, 2015).

Retirement age was traditionally lower within the public sector earnings-related pension scheme, but since 1995 it has been gradually brought in line with the private sector earnings-related pension scheme. Still, public sector employees in certain occupations and with longer service careers are eligible for full pension benefits at a younger age. However, due to transitional provisions some public sector employees have been assigned a higher individual 
retirement age between 63.5 and 65 , while retaining the right to a higher pension accrual. As a result, in 2008 about 70 per cent of public sector employees aged 50 years or over were assigned a higher individual retirement age, while some 25 per cent were entitled to a lower occupational retirement age (Järnefelt and Nivalainen, 2016).

In addition to old-age pensions, several other pension types shape exit pathways from the labour market. People moving from a full-time to a part-time job can receive an earnings-related part-time pension. Until 2011, the part-time pension could be drawn between ages 58 and 67; the lower age limit was then increased to 60 . Those who have been unemployed for at least two years while previously employed for at least five out of 15 years have been eligible for an unemployment pension starting at age 60 . The combination of extended unemployment benefits and unemployment pension has been referred to as the 'unemployment tunnel' (Kyyrä, 2015). Disability pensions are available after long-term sickness and in case of permanently reduced working capacity. A rehabilitation pension is a disability pension paid for a limited period of time only. Partial disability pensions can be awarded in instances of a 40-60 per cent reduction in working capacity.

\section{Data and methods}

\section{Sequence data and analysis}

We used detailed longitudinal register data collected by the Finnish Centre for Pensions of a cohort of men and women born in 1948. The data combined spells of employment, pension receipt and benefit receipt for the period from 2005 until 2013. This meant it was possible to follow the cohort from age 57 until 65 . Those who did not have Finnish nationality or who resided abroad during the follow-up period were excluded from the analysis. There are not many older immigrants in Finland and they often have only brief and interrupted histories of pension accrual. 
For conceptual and practical reasons we only included those who were employed in 2004 at the age of 56. We were interested in trajectories from work to retirement and followed Fasang's (2010) definition of retirement trajectories as 'the sequence of primary income sources within the age bracket during which old age pension entrance is theoretically possible'. Among the various exit pathways, entrance into the 'unemployment tunnel' was the first opportunity for early exit at age 57. Therefore, the inclusion of those who were already permanently outside the labour market at age 56, due to disability or unemployment, would not have contributed to our understanding of the process of retirement among Finnish workers. Furthermore, including this group would have made it even harder to operationalise the independent variables at the onset of the trajectories.

The final study population consisted of 55,971 people. This was 65.4 per cent of the total population aged 56 at the end of 2004 . We checked for the characteristics of those excluded from our study and found that 51.7 per cent in this group were men and 48.3 per cent of women. Among them, the majority were retired on a (disability) pension (44.5\%), unemployed $(31.8 \%)$ or otherwise inactive $(10.0 \%)$. Among both men and women in this group, 47 per cent had no formal educational qualifications. Given that men and women were more or less equally represented in the excluded group, this should have little impact on the gender retirement differences in the included group. Although a group of relatively low educated individuals was excluded from the study population, there were no substantial gender differences in education levels in this group.

Our choice of follow-up period was restricted by the availability of the data only after 2005 and until 2013. As our purpose was to construct trajectories, we chose to have as long a follow-up period as possible, even though this meant limiting the analysis to one birth year only. We selected the month of turning 65 as the right censoring point because, even though retirement under the flexible retirement scheme is possible until 68,65 is the official retirement age under the 
national pension. Moreover, the large majority of older workers have in fact withdrawn from working life by that point (Tuominen, 2013).

The data was used to create sequences of monthly primary income sources. Each sequence comprised 97 months from the month of turning 57 until the month of turning 65 . The 13 sources of income were employment (including self-employment), sickness benefits, unemployment benefits, other benefits, full disability pensions, partial disability pensions, rehabilitation pensions, unemployment pensions, part-time pensions, early retirement pensions, oldage retirement pensions, and other pensions (including special farmers pensions). Those who died during the follow-up period received the status 'deceased'.

We applied sequence analysis with optimal matching techniques to estimate the distances between sequences (Abbott, 1995; Gabadinho et al., 2010). The strength of sequence analysis is that it allows analysing holistic trajectories and offers a way of understanding 'single events in their continuity' (Aisenbrey and Fasang, 2010). We grouped together statuses by theme (e.g. sickness benefits, rehabilitation pensions and disability pensions representing statuses related to health) and by type (employment, benefits, part-time pensions and pensions). Statuses similar by theme and type received a lower substitution cost. Transitions between statuses that were dissimilar by theme or type were assigned higher costs. The cost for transitions to 'deceased' as the ultimate 'absorbing state' was set as the highest. The substitution cost matrix is provided in the Annex. Indel costs were set at slightly higher than 0.5 times the highest substitution cost to ensure that the timing of the transitions matters (Aisenbrey and Fasang, 2010). Different solutions with variations of substitution costs, indel costs and dissimilarity measures were tested, but yielded either similar or less easily interpretable results. Finally, we used the Ward method of cluster analysis to identify the optimal number of clusters (Studer, 2013). 
We linked the data on retirement trajectories clusters to Finnish Longitudinal Employer-Employee Data (FLEED). Collected since 1988 by Statistics Finland, FLEED combines various registers from the tax authorities, employment offices and municipal registers and represents one-third of the Finnish working population aged 15 to 70 . The data is available on an annual basis and includes possibilities to link individuals to employers and spouses. After combining FLEED with the cluster data and removing cases with missing values, 9,194 men and 9,508 women remained in the sample for further analysis. FLEED data from the last week of 2004 was used to analyse the association of the clusters with individual sociodemographic characteristics.

To analyse the gendered work-family life course we included variables for gender, marital status (married, single, divorced or widowed) and having children. To test the effects of social stratification, we included variables for education, occupational status and income. The highest level of educational qualifications was recoded into three categories: lower (no formal qualifications), intermediate (secondary education or basic vocational) and higher (tertiary education). Occupational status was divided into six categories: farmers and forestry entrepreneurs, other self-employed, upper-level employees, lower-level employees, manual workers and other (including students, pensioners, unemployed, others and unknown). Household disposable income is a continuous variable recoded into quartiles. A dummy for working in the public sector was included.

Finally, we measured the incidence of unemployment and sickness in older workers' mid- to late careers to measure vulnerability. FLEED includes data on months in unemployment and annual amount of sickness benefits received from the Social Insurance Institution. This data is highly skewed: a vast majority of people did not experience unemployment or sickness at any point. For unemployment spells we created a variable consisting of three categories: those with no spells of unemployment, those with less than 24 months of unemployment during the period 1995-2004, 
and those with more than 24 months of unemployment during that same period. Sickness absences were captured in a variable with four ordered categories: no receipt of sickness benefits, sickness benefits received during at least one year in the period 1995-2004, sickness benefits received during at least one year in the period 2000-2004, and sickness benefits received in 2004. We also used this to test whether sickness experienced earlier in life has a similar effect on retirement trajectories as sickness later on. As the level of sickness benefits is to some extent dependent on income, it was not possible to identify the lengths of sickness spells in more detail. Table 1 provides descriptive statistics for the explanatory variables and indicates the statistical significance of differences between men and women based on Chi-square tests.

\section{<Table 1 about here>}

We applied multinomial logistic regression to estimate the contribution of these factors to the probability of ending up in each of the trajectories. To disentangle the various effects, the analysis was performed in stages. First, we ran the model with the total sample and all explanatory variables, mainly to identify the effect of the gender dummy on the take-up of each of the trajectories, while controlling for everything else. Next, we split the sample into men and women to analyse whether socioeconomic factors, sector and vulnerability had different effects on men's and women's retirement trajectories. Finally, we split the sample by sector (including only those in employed positions) to further analyse to what extent the gender differences could be attributed to sector of employment and whether socioeconomic factors and vulnerability mattered differently in the private and public sectors. 


\section{Results}

Sequence analysis and descriptive results

Following sequence analysis and subsequent cluster analysis, we chose a solution of eight clusters that best represented the types of retirement trajectories in this cohort (Figure 1). The weighted Average Silhouette Width of the cluster solution was 0.36 , which indicates a reasonable structure (Studer, 2013). This solution was also chosen as optimal, as it closely reflected the expected effects of the main exit pathways in Finland for the period under study. Moreover, complex monthly data with 13 different statuses makes it difficult to find solutions with a higher ASW.

\section{<Figure 1 about here>}

Four clusters represent retirement trajectories through the age-related pension schemes. The largest cluster is 'Standard retirement' (42.3\%), consisting mainly of those who worked until the age of 63 and then retired. Some in this cluster experienced unemployment, but only for shorter spells. Few passed through part-time retirement or early retirement before entering the old-age pension scheme at 63. Those in the 'Long career' cluster (19.7\%) remained employed until at least 64 , or even continued to work beyond 65. This group experienced few disruptions in their late career. 'Early retirement' $(8.3 \%)$ consists of workers who mostly retired before 60 on an occupational or special farmer pension. 'Part-time retirement' (6.7\%) represents the option of combining part-time work with a part-time pension until entering full-time retirement at the age of 63 or later.

We found three types of trajectories that involved 'involuntary' retirement. In the 'Unemployment' trajectory (10.5\%), the unemployed predominantly retired on an unemployment pension after the age of 60 , having received extended unemployment benefits for the maximum period of time. At the age of 63 they transited into the old-age pension system. There were two trajectories involving sickness and disability: 'Disability' (5.6\%) and 'Long-term disability' (4.3\%). 
Those in the 'Disability' trajectory mostly entered disability or partial disability pension arrangements after the age of 59, after a period of sickness benefits, and then retired on an old-age pension at the age of 63 . This cluster includes those who drew a partial disability pension. Those in 'Long-term disability' mostly entered the disability pension scheme before the age of 59, and for a large part did not move on to old-age pension system until the age of 65 . The distinction between these two disability trajectories is largely attributable to a policy reform introduced in 2006 . Those for whom the insured event took place before 2006 entered into an old-age pension at the age of 65 . Disability pensions based on insured events after 2006 were converted into old-age pensions at the age of 63. Finally, those who died during the follow-up period were grouped in a separate trajectory (2.6\% of the study population).

Table 1 shows that the differences between men and women in the take-up of various trajectories are fairly small, but nonetheless statistically significant. Table 1 also illustrates the sociodemographic differences between men and women. Men were more often married and women more often divorced or widowed, but there were no significant differences in having children. Men were more often higher educated and employed in agriculture, self-employment, upper-level whitecollar jobs, manual work, and in the private sector. Women were more often lower-level employees and employed in the public sector. There were no clear differences in terms of vulnerability. Spells of unemployment were somewhat more common among men, whereas sickness absences were more common among women.

\section{Multinomial logistic regression models}

We used the 'Standard retirement' category as the reference group in the multinomial logistic regression models. Multiple significance testing presented some problems due to the large number of categories in our models. We controlled for the false discovery rate using Benjamini and 
Hochberg's (1995) procedure of adjusting $p$-values. Table 2 presents the results of the multinomial logistic regression model for the whole population. Testing the gendered life course hypothesis, it shows that there were only few statistically significant gender differences in the take-up of the various trajectories. When controlling for all other factors, women were more likely to enter into 'Part-time retirement' and less likely to become long-term disabled or to die in the follow-up period.

\section{<Table 2 about here>}

Being single or divorced increased the likelihood of having a 'Long career', while being married increased the likelihood of 'Part-time retirement' (Table 2). A separate examination of these results for men (Table 3) and women (Table 4) showed that marital status had no impact on men's retirement, but being divorced increased the likelihood of a 'Long career' and 'Disability' among women, and decreased their likelihood of 'Early retirement and 'Part-time retirement'. 'Parttime retirement' was also less likely among single and widowed women, suggesting that this trajectory is associated with family reasons for women. It is possible that they coordinated their retirement with their retired husbands, or that they chose to work less to care for family members. We found that having had children did not have an effect on the timing of retirement among either women or men, although it did decrease the likelihood of 'Unemployment' among women. Overall, these results confirm that the 'institution of family', and marriage and divorce in particular, affected women's retirement only, although we found no strong support for the compensation or status maintenance hypotheses of family formation.

\section{$<$ Tables 3 and 4 about here>}

Socioeconomic factors had varying effects on men's and women's retirement trajectories (Tables 3 and 4). One the one hand, higher educated women, but not men, were more likely to have 'Long careers'. This finding is in support of the status maintenance hypothesis, 
suggesting that higher educated women were more strongly attached to the labour market. On the other hand, and in contradiction with the status maintenance hypothesis, higher educated women were also more likely to move into 'Early retirement'. However, these contrasting findings are most likely due to the high proportion of educated women working in the public sector, where those with an occupational retirement age retired early and those with an individual retirement age retired later. Among both men and women, having higher education lowered the risk of 'Unemployment'. An intermediate level education lowered women's risk of entering the 'Long-term disability' trajectory, while higher education lowered men's risk of 'Disability'. For men, a higher education increased the likelihood of entering 'Part-time retirement'.

Among both men and women, farmers were more likely to have 'Long careers' as well as 'Early retirement', but less likely to enter 'Unemployment'. Self-employed men and women were also more likely to have 'Long careers' and less likely to enter 'Unemployment, but at the same time less likely to retire early. Manual workers were less likely to enter 'Early retirement', but more likely to enter 'Disability'. Male upper-level employees were less likely to enter into 'Early retirement' or 'Unemployment', while female manual workers more likely to end up in 'Unemployment' or 'Long-term disability'. This contradicts the 'primacy of class thesis', as it mattered whether an upper-level employee or a manual worker was a man or a woman.

Among the socioeconomic factors, income had the most divergent effects on men and women's retirement. Higher income had a positive association with 'Long career' for women, but not for men. This is again in support of the status maintenance hypothesis. Being in the third or fourth income quartile among men and in the highest quartile among women had a statistically significant positive association with 'Early retirement', indicating that the income threshold for retiring early was higher for women than for men. Level of income had a positive effect on the likelihood of 'Part-time retirement' among men, but not women. This suggests that for men, parttime retirement was driven by financial factors, possibly because of their role as primary 
breadwinner even in dual earner households. At the same time, belonging to a higher income quartile lowered the risk of 'Unemployment' and 'Disability' among women, but not men. This again contradicts the 'primacy of class thesis': women in better-paid jobs were at a lower risk of involuntary exit, while for men income status had no such effect.

There were differences between men and women in the impact of unemployment and spells of sickness absence on retirement trajectory (Tables 3 and 4). As expected, the incidence of unemployment increased the risk of exit through the 'Unemployment' trajectory, while the incidence of sickness absences increased the risk of exit through both disability trajectories. At the same time, the incidence of sickness absences increased the risk of exit through 'Unemployment'. Among women, the incidence of long-term unemployment decreased the likelihood of exit through both disability trajectories. Among women but not men, there was a significant positive association between unemployment spells and 'Long career', which supports the compensation hypothesis. However, the incidence of sickness spells decreased the likelihood of a 'Long career' for women. The experience of unemployment lowered the probability of exit through 'Early retirement' and 'Part-time retirement' for both men and women, which is probably due to eligibility rules based on tenure with the same employer. The incidence of sickness among both men and women increased the likelihood of exit through 'Early retirement'.

Working in the public sector had strong and statistically significant effects on each of the trajectory types, while controlling for all other factors (Table 2). These effects were positive for 'Long career', 'Early retirement' and 'Part-time retirement', and negative for 'Unemployment' for both men and women (Tables 3 and 4). Employment in the public sector had a statistically significant positive effect on the risk of 'Disability' and 'Long-term disability' only in the case of women. Tables 5 and 6 show that the factors affecting retirement trajectories differed substantially between the private and public sectors. In the public sector, women were significantly less likely than men to enter into 'Long career' or 'Early retirement', in the private sector more likely to do so 
(though not statistically significantly). Women in the private sector were more likely than men to enter 'Part-time retirement', but less likely to enter 'Long-term disability'. In the public sector, women were more likely to end up in 'Disability'.

\section{<Tables 5 and 6 about here>}

It should be noted that with the sector-specific models, the explained variance differed considerably. Nagelkerke's R-square was 0.27 for the public sector (Table 6), but only 0.11 for the private sector (Table 5). This might be due to farmers and self-employed being excluded in these models, both occupations that occur only in the private sector. Interestingly, in terms of statistically significant associations and effect sizes, the results for the private sector show much overlap with the results for men and those for the public sector with those for women. Upper-level employees and manual workers were less likely to exit through 'Early retirement' than lower-level employees in the public sector only. Being a manual worker had a statistically significant positive effect on exit through the disability trajectories in the public sector, but not in the private sector. Additionally, income was associated with 'Long career', 'Early retirement' and 'Unemployment' in the public sector only and with 'Part-time retirement' in the private sector only.

\section{Discussion and conclusions}

This study investigated the factors that shape men's and women's retirement trajectories in Finland. We asked whether it is possible to assume that men's and women's labour market withdrawal is similar in timing and mode when, in contrast to almost all other countries, women's rate of labour market participation is higher than men's. We applied sequence analysis to identify broad types of retirement trajectories. The advantage of this approach is that it allows us to analyse individual variation in retirement patterns in institutional contexts that have a strong 'structuring' impact, such as the Finnish pension system and its several exit pathways (Fasang, 2010). 
We found eight distinct trajectories that differed in terms of timing of retirement (early, at the statutory retirement age and late) and that were shaped by exit pathways (old-age, parttime, unemployment and disability pensions). Comparable studies in the United States, Germany, the United Kingdom and the Netherlands discovered gender differences in the use of retirement trajectories (Calvo, Madero-Cabib and Staudinger, 2017; Fasang, 2010; Riekhoff, 2016). However, when controlling for other factors, there were no substantial gender differences in the Finnish context. The main contrast to other country studies was that we did not find a female-dominated trajectory for non-employment. This is explained in part by the sampling criterion of being employed in 2004 and to the absence of 'no own income' as a separate income status in the data. Nevertheless, inactivity rates are low in Finland and most people receive some type of benefit or pension.

We tested several hypotheses that explain gender differences in retirement. First, we found support for the 'gendered life course thesis' and the importance of family situation, even in a country with high employment rates for women and a wide array of policies that allow women more opportunities to combine work and family than in many other countries. Still, married women retired more often on a part-time pension, implying that 'the institution of family' and related care roles or husband's retirement leads them to work shorter hours (Denaeghel, Mortelmans and Borghgraef, 2011).

Divorced women were more likely to have a 'Long career' and less likely to retire early or on a part-time pension. This may be the other side of the same coin: divorced women did not have the incentive to retire earlier together with a husband. At the same time, it is in line with the compensation hypothesis and research which has found that divorced women need to make up for foregone pension accruals (Fasang, Aisenbrey and Schömann, 2013; Finch, 2014). However, in contrast to women in Germany and the UK, it was rare for Finnish women to enter the labour market only after a divorce. Rather, the reason for their later retirement lies more likely in the high 
costs of living alone, resulting in the need to continue work in order to secure a sufficient income. There was no evidence that having had children affected career length and retirement timing any differently for women and men in Finland. This is in contrast with findings from a recent study on two other Nordic countries, Sweden and Denmark, where longer career breaks for women were associated with later retirement (König, 2017).

Second, we found no strong support for the 'primacy of class thesis': there were clear differences between men and women in how socioeconomic factors influenced retirement (Radl, 2013). Rather, we found that our results supported a socioeconomic status maintenance hypothesis. Income was particularly instrumental in explaining women's later retirement, but not men's. The results are in line with an earlier study on Norway (Dahl, Nilsen, and Vaage, 2003) and suggest that for women, being in better and higher-paid jobs creates incentives to maintain such positions and lowers risks of involuntary early exit.

Higher education was associated with women's 'Early retirement' and 'Long careers'. This result is likely due to an interaction between gender and sector. In the Finnish public sector, certain female-dominated occupations that require tertiary-level education, such as teachers and nurses, have a lower occupational retirement age, causing women in particular to retire early. At the same time, those in the public sector with no occupational retirement age received an individual retirement age after the 2005 reform, which may be later than 63. This has affected higher educated workers in particular, who have been less likely than lower educated workers to exit early through disability pensions (Järnefelt and Nivalainen, 2016).

There was no substantial evidence that women were more vulnerable in their late careers than men. Rather, men and women experienced different vulnerabilities. The rate of sickness absences was somewhat higher among women and when they occurred, they decreased women's likelihood of having a 'Long career'. Similarly to Raymo et al. (2011) in the United States, we found that late career job loss was associated with a deferral of retirement among 
women, but not among men. It is unclear from this study whether retirement is deferred for financial reasons, but this would be in line with the compensation hypothesis: later retirement is needed to compensate foregone earnings due to job loss.

Finally, one of the novelties of this study is our analysis of the role of public sector employment. We found that retirement in the public sector was fundamentally different from the private sector. Because women were employed in the public sector more often than men, women's retirement patterns largely overlapped with patterns in the public sector, whereas men's retirement overlapped more closely with patterns in the private sector. The findings suggest an interaction between gender, public sector and education, leading to higher educated women in the public sector to retire either early or late, depending on their occupation. Unemployment is less prevalent in the public sector. However, our results partly support the earlier finding that among women in the public sector, retirement on disability pensions has served as a substitute for the 'unemployment tunnel’ exit pathway (Järnefelt, 2010; Kyyrä, 2015).

One limitation of the trajectory approach to retirement is that it yields broad and static categories of retirement patterns, leaving limited scope to control for the dynamics within those patterns. For studies concerned with the exact timing of retirement, survival analysis methods are more useful. Our study showed that retirement involves complex patterns of consecutive transitions that are shaped by individual characteristics and the institutional context. The 'holistic' use of trajectories as sequences of events should also be particularly useful for policy-making purposes. By identifying risky events or transitions early on in the trajectories, policy interventions could be more effectively aimed at averting definite withdrawal from the labour market later on.

This study shows that in Finland, gender differences in retirement trajectories are not large, but factors explaining allocation to each of the trajectories differ substantially by gender. We looked at these factors from various theoretical perspectives, but found that none of them dominates. Each of these factors rather can be seen in relation to each other across life courses and 
in their specific institutional context (Krüger and Levy, 2001). Gender-specific cultural norms and structural incentives not only affect educational, occupational and family choices earlier in life, leading to variation in late career vulnerabilities, but they also shape decisions on how to combine work, family and leisure at the time of retiring. In this study, this was especially visible in the impact of public sector employment on retirement trajectories in Finland. The public sector has been key to women's employment, not only by providing jobs, but also by producing the services that allow combining work and family life. At the same time, it has imposed different rules and norms in shaping retirement, while creating gendered occupations that do not necessarily correlate with socioeconomic position. Although a large and female-dominated public sector is to some extent a typical trait of Finland's Nordic-type of welfare state, its impact illustrates how gender differences in retirement are shaped by life course institutionalization. 


\section{References}

Abbott, A. (1995). Sequence analysis: new methods for old ideas, Annual Review of Sociology, 21, 93-113.

Aisenbrey, S. and Fasang, A.E. (2010). New life for old ideas: the 'second wave' of sequence analysis bringing the course back into the life course, Sociological Methods \& Research, 38, 420-462.

Benjamini, Y. and Hochberg, Y. (1995). Controlling the false discovery rate: a practical and powerful approach to multiple testing, Journal of the Royal Statistical Society: Series B, 57, 289-300.

Blossfeld, H.-P., Buchholz, S. and Hofäcker, D. (eds.) (2006). Globalization, Uncertainty and Late Careers in Society. New York: Routledge.

Calvo, E., Madero-Cabib, I. and Staudinger, U.M. (2017). Retirement sequences of older Americans: moderately destandardised and highly stratified across gender, class, and race, The Gerontologist, ahead of print publication, 1-11.

Chan, S. and Stevens, A.H. (1999). Employment and retirement following a late-career job loss, The American Economic Review, 89, 211-216.

Dahl, S.-A., Nilsen, Ø.A. and Vaage, K. (2003). Gender differences in early retirement behaviour, European Sociological Review, 19, 179-198.

Denaeghel, K., Mortelmans, D. and Borghgraef, A. (2011). Spousal influence on the retirement decisions of single-earner and dual-earner couples, Advances in Life Course Research, 16, 112123.

De Preter, H., Mortelmans, D. and Van Looy, D. (2012). Retirement timing in Europe: does sector make a difference?, Industrial Relations Journal, 43, 511-526. 
Ebbinghaus, B. (2006). Reforming Early Retirement in Europe, Japan and the USA. Oxford: Oxford University Press.

Eurostat (2016). Employment and activity by sex and age - annual data. Retrieved from http://ec.europa.eu/eurostat/data/database [October 2016].

ETK and Kela (2015). Statistical Yearbook of Pensioners in Finland 2014. Helsinki: Juvenes Print.

Fasang, A.E. (2010). Retirement: institutional pathways and individual trajectories in Britain and Germany, Sociological Research Online, 15. Available online at http://www.socresonline.org.uk/15/2//1.html.

Fasang, A.E., Aisenbrey, S. and Schömann, K. (2013). Women's retirement income in Germany and Britain, European Sociological Review, 29, 968-980.

Finch, N. (2014). Why are women more likely than men to extend paid work? The impact of workfamily life history, European Journal of Ageing, 11, 31-39.

Gabadinho, A. et al. (2010). Mining Sequence Data in R with the TraMineR Package: A User's Guide. University of Geneva. Available online at http://mephisto.unige.ch/pub/TraMineR/doc/1.4/TraMineR-1.4-Users-Guide.pdf [January 2014].

Henkens, K. and Van Solinge, H. (2002). Spousal influences on the decision to retire, International Journal of Sociology, 32, 55-74.

Järnefelt, N. (2010). Education and longer working lives. A longitudinal study on education differences in the late exit from working life of older employees in Finland. Finnish Centre for Pensions, Studies 2010/1.

Järnefelt, N. and Nivalainen, S. (2016) Why later retirement intentions in the public sector compared to the private sector? In: N. Järnefelt (ed.) Working Conditions and Working Lives - 
Research on the Stability of Working Lives and Retirement. Finnish Centre for Pensions, Studies 08/2016, pp. 201-25.

König, S. (2017). Career histories as determinants of gendered retirement timing in the Danish and Swedish pension systems, European Journal of Ageing, ahead of print online publication.

Krüger, H. and Levy, R. (2001). Linking life courses, work and the family: theorizing a not so visible nexus between women and men, Canadian Journal of Sociology, 26, 145-166.

Kurvinen, A. et al. (2016). Late career job loss - employment trajectories and retirement of displaced workers aged above 45 years. Finnish Centre for Pensions, Studies 02/2016.

Kyyrä, T. (2015). Early retirement policy in the presence of competing exit pathways: evidence from pension reforms in Finland, Economica, 82, 46-78.

Madero-Cabib, I. (2015). The life course determinants of vulnerability in late careers, Longitudinal and Life Course Studies, 6, 88-106.

Madero-Cabib, I. and Fasang, A.E. (2016). Gendered work-family life courses and financial wellbeing in retirement, Advances in Life Course Studies, 27, 43-60.

OECD (2014). The economic consequences of ageing. In: OECD Economic Surveys: Finland 2014. Paris: OECD Publishing.

Radl, J. (2013). Labour market exit and social stratification in Western Europe: the effects of social class and gender on the timing of retirement, European Sociological Review, 29, 654-668.

Rantala, J. and Riihelä, M. (2016). Income differences between retired men and women in 19952013. Finnish Centre for Pensions, Reports 01/2016.

Raymo, J.M. et al. (2011). Precarious employment, bad jobs, labor unions, and early retirement. Journal of Gerontology: Social Sciences, 66B, 249-259. 
Riekhoff, A.J. (2016). Institutional and socio-economic drivers of work-to-retirement trajectories in the Netherlands, Ageing \& Society, ahead of print publication, 1-26.

Studer, M. (2013). WeightedCluster library manual: a practical guide to creating typologies of trajectories in the social sciences with R. LIVES Working Papers, no. 24. Available online at http://dx.doi.org/10.12682/lives.2296-1658.2013.24 [March 2015].

Takala, M. and Väänänen, N. (2016). Does part-time pension extend working lives? Finnish Centre for Pensions, Reports 05/2016.

Tuominen, E. (2013). Flexible retirement in Finland. The evaluation of the Finnish flexible retirement scheme in light of employer and employee surveys. Finnish Centre for Pensions, Working Papers 03/2013. 
Figure 1: State distribution plots for the eight-cluster solution of sequence analysis.
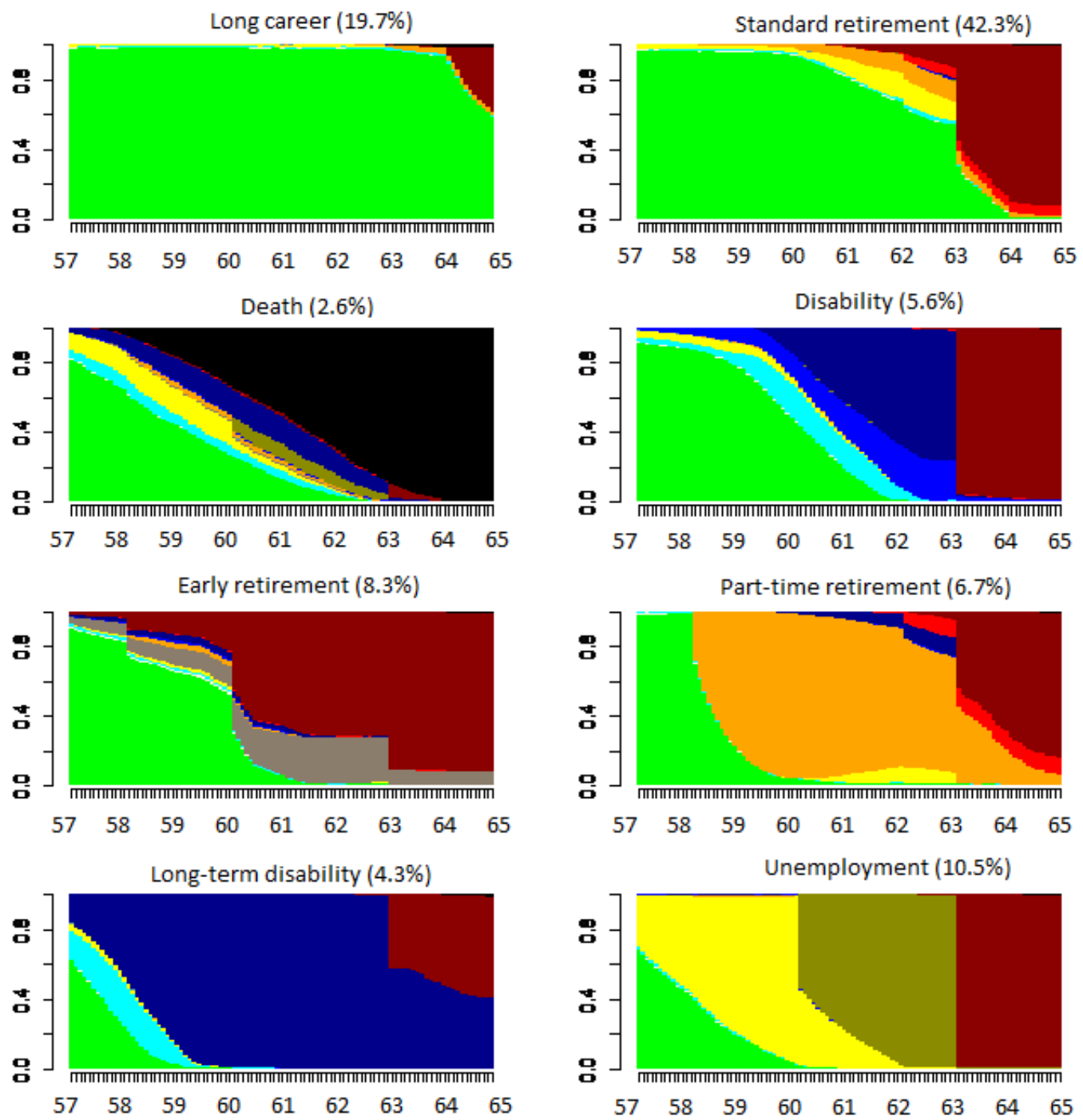

\begin{tabular}{|llll|}
\hline$\square$ Employed & $\square$ Unemployment benefits & $\square$ Part-time pension & $\square$ Full disability pension \\
$\square$ Other benefits & $\square$ Other pensions & $\square$ Partial disability pension & $\square$ Early retirement pension \\
$\square$ Sickness benefits & $\square$ Rehabilitation pension & $\square$ Unemployment pension & $\square$ Old-age pension \\
\hline
\end{tabular}


Table 1: Descriptive statistics of dependent and independent variables

\begin{tabular}{|c|c|c|c|c|c|c|}
\hline & & Men & $\%$ & Women & $\%$ & $\mathrm{P}$-value \\
\hline \multirow[t]{8}{*}{ Trajectory } & $\begin{array}{l}\text { Standard } \\
\text { retirement }\end{array}$ & 3,957 & 43.0 & 3,972 & 41.8 & $>0.001$ \\
\hline & Long career & 1,843 & 20.0 & 1,923 & 20.2 & \\
\hline & Early retirement & 706 & 7.7 & 767 & 8.1 & \\
\hline & $\begin{array}{l}\text { Part-time } \\
\text { retirement }\end{array}$ & 545 & 5.9 & 695 & 7.3 & \\
\hline & Unemployment & 952 & 10.4 & 969 & 10.2 & \\
\hline & Disability & 475 & 5.2 & 599 & 6.3 & \\
\hline & $\begin{array}{l}\text { Long-term } \\
\text { disability }\end{array}$ & 406 & 4.4 & 406 & 4.3 & \\
\hline & Death & 310 & 3.4 & 177 & 1.9 & \\
\hline \multirow[t]{4}{*}{ Marital status } & Married & 6,708 & 73.0 & 6,247 & 65.7 & $>0.001$ \\
\hline & Not married & 939 & 10.2 & 937 & 9.9 & \\
\hline & Divorced & 1,398 & 15.2 & 1,813 & 19.1 & \\
\hline & Widowed & 149 & 1.6 & 511 & 5.4 & \\
\hline \multirow[t]{2}{*}{ Children } & Children & 7,428 & 85.0 & 7,504 & 84.0 & 0.061 \\
\hline & No children & 1,306 & 15.0 & 1,427 & 16.0 & \\
\hline \multirow[t]{3}{*}{ Education } & Lower & 3,050 & 33.2 & 2,898 & 30.5 & $>0.001$ \\
\hline & Intermediate & 4,377 & 47.6 & 5,333 & 56.1 & \\
\hline & Higher & 1,767 & 19.2 & 1,277 & 13.4 & \\
\hline \multirow{6}{*}{$\begin{array}{l}\text { Occupational } \\
\text { status }\end{array}$} & Farmers & 590 & 6.4 & 287 & 3.0 & $>0.001$ \\
\hline & $\begin{array}{l}\text { Other self- } \\
\text { employed }\end{array}$ & 1,233 & 13.4 & 635 & 6.7 & \\
\hline & $\begin{array}{l}\text { Upper-level } \\
\text { employees }\end{array}$ & 2,009 & 21.9 & 1,604 & 16.9 & \\
\hline & $\begin{array}{l}\text { Lower-level } \\
\text { employees }\end{array}$ & 1,644 & 17.9 & 4,516 & 47.5 & \\
\hline & Manual workers & 3,346 & 36.4 & 2,198 & 23.1 & \\
\hline & Other & 372 & 4.0 & 268 & 2.8 & \\
\hline \multirow{4}{*}{$\begin{array}{l}\text { Income } \\
\text { quartile }\end{array}$} & First (lowest) & 2,369 & 26.2 & 2,270 & 23.9 & $>0.001$ \\
\hline & Second & 2,368 & 25.9 & 2,292 & 24.1 & \\
\hline & Third & 2,241 & 24.5 & 2,427 & 25.5 & \\
\hline & Fourth (highest) & 2,151 & 23.5 & 2,514 & 26.5 & \\
\hline \multirow[t]{2}{*}{ Sector } & Private & 7,343 & 79.9 & 4,895 & 51.5 & $>0.001$ \\
\hline & Public & 1,851 & 20.1 & 4,613 & 48.5 & \\
\hline \multirow{3}{*}{$\begin{array}{l}\text { Months in } \\
\text { unemployment } \\
\text { in last ten } \\
\text { years }\end{array}$} & Zero & 7,048 & 76.7 & 7,364 & 77.5 & 0.003 \\
\hline & Less than 24 & 1,304 & 14.2 & 1,200 & 12.6 & \\
\hline & More than 24 & 842 & 9.2 & 944 & 9.9 & \\
\hline \multirow[t]{4}{*}{ Sickness spells } & Zero & 7,214 & 78.5 & 7,139 & 75.1 & $>0.001$ \\
\hline & $\begin{array}{l}\text { During at least } \\
\text { one year in the } \\
\text { past ten years }\end{array}$ & 270 & 2.9 & 326 & 3.4 & \\
\hline & $\begin{array}{l}\text { During at least } \\
\text { one year in the } \\
\text { past five years }\end{array}$ & 1,120 & 12.2 & 1,357 & 14.3 & \\
\hline & In 2004 & 590 & 6.4 & 686 & 7.2 & \\
\hline
\end{tabular}

Note: P-values are based on two-sided Chi-square tests for differences between men and women. 
Table 2: Multinomial regression model for work-to-retirement trajectories: whole population

\begin{tabular}{|c|c|c|c|c|c|c|c|c|}
\hline & & $\begin{array}{l}\text { Long } \\
\text { career }\end{array}$ & $\begin{array}{l}\text { Early } \\
\text { retirement }\end{array}$ & $\begin{array}{l}\text { Part-time } \\
\text { retirement }\end{array}$ & Unemployment & Disability & Long disability & Death \\
\hline Female (ref. $=$ Male $)$ & & 0.926 & 0.874 & $1.181 *$ & 1.101 & 1.117 & $0.818^{*}$ & $0.474 * *$ \\
\hline \multirow[t]{3}{*}{ Marital status (ref. = Married) } & Not married & $1.248 *$ & 0.802 & $0.481 * *$ & 0.947 & 1.073 & 1.041 & 1.298 \\
\hline & Divorced & $1.299 * *$ & 0.882 & $0.694 * *$ & 0.897 & 1.129 & 1.109 & $1.411^{*}$ \\
\hline & Widowed & 1.050 & 1.012 & $0.617 *$ & 1.115 & 1.241 & 1.051 & 1.207 \\
\hline Children (ref. = No children) & & 1.111 & 1.052 & 1.014 & $0.826^{*}$ & 0.999 & 0.843 & 0.978 \\
\hline \multirow[t]{2}{*}{ Education (ref. = Lower) } & Intermediate & 1.026 & 1.141 & 1.100 & 0.884 & 0.868 & $0.824^{*}$ & 0.849 \\
\hline & Higher & $1.487 * *$ & 1.308 & 1.329 & $0.603 * *$ & $0.619 *$ & $0.602 *$ & 0.908 \\
\hline \multirow[t]{5}{*}{$\begin{array}{l}\text { Occupational status } \\
\text { (ref. = Lower-level employees) }\end{array}$} & Farmers & $4.305 * *$ & $7.125 * *$ & 0.603 & $0.055 * *$ & 1.179 & 1.257 & 1.693 \\
\hline & Other self-employed & $1.620 * *$ & $0.485 * *$ & 1.047 & $0.242 * *$ & 1.225 & 0.725 & 0.742 \\
\hline & Upper-level employees & 1.047 & $0.791 *$ & 0.832 & 0.812 & 0.853 & 0.724 & 0.716 \\
\hline & Manual workers & 0.928 & $0.691 * *$ & 1.076 & 1.160 & $1.504 * *$ & $1.598 * *$ & 1.145 \\
\hline & Other & 1.174 & $2.150 * *$ & $0.349 *$ & $2.621 * *$ & 1.296 & $4.229 * *$ & 1.130 \\
\hline \multirow[t]{3}{*}{ Income (ref. $=$ Lowest quartile) } & Second quartile & 1.143 & 0.798 & $1.491 * *$ & $0.806^{*}$ & 1.006 & 0.901 & 0.754 \\
\hline & Third quartile & $1.230 * *$ & $1.423 * *$ & $1.339 *$ & 0.836 & 0.807 & 0.860 & 0.841 \\
\hline & Highest quartile & $1.357 * *$ & $1.783 * *$ & $1.412 * *$ & 0.880 & $0.699 *$ & $0.695^{*}$ & 0.786 \\
\hline Public sector (ref. $=$ Private sector) & & $1.914 * *$ & $2.092 * *$ & $1.607 * *$ & $0.504 * *$ & $1.761 * *$ & $2.131 * *$ & $1.334 *$ \\
\hline \multirow[t]{2}{*}{ Months in unemployment (last 10 years) $($ ref. $=0)$} & Less than 24 months & $1.182 *$ & $0.278 * *$ & $0.745^{*}$ & $1.455 * *$ & 1.113 & 0.985 & 0.899 \\
\hline & $\begin{array}{l}\text { More than } 24 \text { months } \\
\text { During at least } 1 \text { year }\end{array}$ & $1.248 *$ & $0.303 * *$ & $0.323 * *$ & $3.232 * *$ & 0.762 & 0.809 & $1.853 * *$ \\
\hline \multirow[t]{3}{*}{ Sickness days (ref. $=0$ ) } & $\begin{array}{l}\text { in the past } 10 \text { years } \\
\text { During at least } 1 \text { year }\end{array}$ & $0.693 *$ & 1.090 & 1.409 & $1.820 * *$ & $2.449 * *$ & $6.788 * *$ & $2.325^{* *}$ \\
\hline & in the past 5 years & 0.980 & $1.459 * *$ & 1.175 & $1.743 * *$ & $2.884 * *$ & $4.977 * *$ & $1.905 * *$ \\
\hline & In 2004 & 0.921 & 1.050 & 0.903 & 1.036 & $1.707 * *$ & $2.173 * *$ & 1.019 \\
\hline Nagelkerke $\mathrm{R}^{2}$ & 0.218 & & & & & & & \\
\hline $\mathrm{N}$ & 17,623 & & & & & & & \\
\hline
\end{tabular}

Note: Indicated are odds ratios. Reference category of the dependent variables is 'Standard retirement'. $* \mathrm{p}<0.05, * * \mathrm{p}<0.01$. 
Table 3: Multinomial regression model for work-to-retirement trajectories: men

\begin{tabular}{|c|c|c|c|c|c|c|c|c|}
\hline & & $\begin{array}{l}\text { Long } \\
\text { career }\end{array}$ & $\begin{array}{l}\text { Early } \\
\text { retirement }\end{array}$ & $\begin{array}{l}\text { Part-time } \\
\text { retirement }\end{array}$ & Unemployment & Disability & Long disability & Death \\
\hline \multirow[t]{3}{*}{ Marital status (ref. = Married) } & Not married & 1.314 & 0.760 & 0.805 & 1.007 & 1.470 & 1.140 & 1.267 \\
\hline & Divorced & 1.044 & 1.101 & 0.838 & 0.941 & 0.927 & 1.173 & $1.729 * *$ \\
\hline & Widowed & 0.882 & 0.767 & 0.854 & 1.131 & 0.892 & 0.882 & 1.521 \\
\hline Children (ref. = No children) & & 1.167 & 1.000 & 0.922 & 0.869 & 1.171 & 0.886 & 0.963 \\
\hline \multirow[t]{2}{*}{ Education (ref. = Lower) } & Intermediate & 1.005 & 1.049 & 1.123 & 0.908 & 0.835 & 0.921 & 0.878 \\
\hline & Higher & 1.241 & 0.922 & $1.543 *$ & $0.594 * *$ & $0.540 *$ & 0.595 & 0.884 \\
\hline \multirow[t]{5}{*}{$\begin{array}{l}\text { Occupational status } \\
\text { (ref. = Lower-level employees) }\end{array}$} & Farmers & $3.941 * *$ & $6.682 * *$ & 0.859 & $0.059 * *$ & 1.067 & 0.884 & 1.744 \\
\hline & Other self-employed & $1.512 * *$ & $0.430 * *$ & 1.336 & $0.144 * *$ & 1.299 & 0.573 & 0.823 \\
\hline & Upper-level employees & 1.095 & $0.668 *$ & 0.860 & $0.693 *$ & 1.276 & 0.526 & 0.646 \\
\hline & Manual workers & 0.835 & $0.639 * *$ & 1.162 & 0.941 & $1.724 * *$ & 1.233 & 1.135 \\
\hline & Other & 1.280 & $2.168 *$ & 0.181 & $2.736 * *$ & 1.931 & 2.791 & 1.281 \\
\hline \multirow[t]{3}{*}{ Income (ref. = Lowest quartile) } & Second quartile & 1.168 & 1.111 & $1.783 * *$ & 0.949 & 1.112 & 1.039 & 0.928 \\
\hline & Third quartile & 1.160 & $1.811 * *$ & $1.579 *$ & 0.999 & 0.930 & 0.844 & 0.993 \\
\hline & Highest quartile & 1.260 & $1.517 *$ & $1.637 *$ & 1.137 & 0.703 & 0.661 & 0.839 \\
\hline Public sector (ref. $=$ Private sector) & & $2.292 * *$ & $3.115 * *$ & $1.820 * *$ & $0.641 * *$ & 1.168 & 1.840 & $1.661 * *$ \\
\hline \multirow[t]{2}{*}{ Months in unemployment (last 10 years) $($ ref. $=0)$} & Less than 24 months & 0.955 & $0.209 * *$ & $0.519 * *$ & 1.194 & 1.093 & 1.024 & 0.924 \\
\hline & $\begin{array}{l}\text { More than } 24 \text { months } \\
\text { During at least } 1 \text { year }\end{array}$ & 0.997 & $0.331 * *$ & $0.298 * *$ & $2.535 * *$ & 1.014 & 1.326 & $2.196 * *$ \\
\hline \multirow[t]{3}{*}{ Sickness days (ref. $=0$ ) } & $\begin{array}{l}\text { in the past } 10 \text { years } \\
\text { During at least } 1 \text { year }\end{array}$ & 0.784 & 0.817 & 1.212 & 1.488 & $2.650 * *$ & $4.552 * *$ & $2.132 *$ \\
\hline & in the past 5 years & 1.031 & $1.420^{*}$ & 1.216 & $1.698 * *$ & $3.101 * *$ & $4.953 * *$ & $2.043 * *$ \\
\hline & In 2004 & 0.959 & 0.772 & 0.949 & 1.150 & $1.870 * *$ & $2.248 * *$ & 0.879 \\
\hline Nagelkerke $\mathrm{R}^{2}$ & 0.225 & & & & & & & \\
\hline $\mathrm{N}$ & 8,697 & & & & & & & \\
\hline
\end{tabular}


Table 4: Multinomial regression model for work-to-retirement trajectories: women

\begin{tabular}{|c|c|c|c|c|c|c|c|c|}
\hline & & $\begin{array}{l}\text { Long } \\
\text { career }\end{array}$ & $\begin{array}{l}\text { Early } \\
\text { retirement }\end{array}$ & $\begin{array}{l}\text { Part-time } \\
\text { retirement }\end{array}$ & Unemployment & Disability & Long disability & Death \\
\hline \multirow[t]{3}{*}{ Marital status (ref. = Married) } & Not married & 1.187 & 0.836 & $0.256 * *$ & 1.012 & 0.686 & 0.900 & 1.497 \\
\hline & Divorced & $1.519 * *$ & $0.734 *$ & $0.619 * *$ & 0.899 & $1.295^{*}$ & 1.047 & 0.919 \\
\hline & Widowed & 1.127 & 1.019 & $0.550 *$ & 1.130 & 1.382 & 1.046 & 0.940 \\
\hline Children (ref. = No children) & & 0.457 & 1.143 & 1.119 & $0.784 *$ & 0.872 & 0.817 & 1.062 \\
\hline \multirow[t]{2}{*}{ Education (ref. = Lower) } & Intermediate & 1.066 & 1.242 & 1.108 & 0.860 & 0.875 & $0.700 * *$ & 0.799 \\
\hline & Higher & $1.839 * *$ & $1.792 * *$ & 1.136 & $0.509^{*}$ & 0.753 & 0.611 & 0.921 \\
\hline \multirow[t]{5}{*}{$\begin{array}{l}\text { Occupational status } \\
\text { (ref. = Lower-level employees) }\end{array}$} & Farmers & $4.340 * *$ & $7.138 * *$ & 0.318 & $0.037 * *$ & 1.591 & 1.913 & 1.665 \\
\hline & Other self-employed & $1.726^{* *}$ & $0.529 *$ & 0.719 & $0.376 * *$ & 1.386 & 0.904 & 0.533 \\
\hline & Upper-level employees & 0.933 & 0.785 & 0.844 & 0.793 & 0.657 & 0.843 & 0.832 \\
\hline & Manual workers & 1.013 & $0.543 * *$ & 1.091 & $1.328 * *$ & $1.449 * *$ & $1.786 * *$ & 1.062 \\
\hline & Other & 1.067 & 1.778 & 0.488 & $2.376^{* *}$ & 0.814 & $5.526 * *$ & 0.697 \\
\hline \multirow[t]{3}{*}{ Income (ref. = Lowest quartile) } & Second quartile & 1.142 & $0.560 * *$ & 1.282 & $0.714 * *$ & 0.882 & 0.790 & $0.535^{*}$ \\
\hline & Third quartile & $1.296^{*}$ & 1.167 & 1.162 & $0.723 *$ & $0.689 *$ & 0.897 & 0.680 \\
\hline & Highest quartile & $1.448 * *$ & $2.016 * *$ & 1.296 & 0.746 & $0.674^{*}$ & 0.728 & 0.695 \\
\hline Public sector (ref. $=$ Private sector) & & $1.699 * *$ & $1.644 * *$ & $1.456 * *$ & $0.451 * *$ & $2.254 * *$ & $2.661 * *$ & 1.304 \\
\hline \multirow[t]{2}{*}{ Months in unemployment (last 10 years) $($ ref. $=0)$} & Less than 24 months & $1.477 * *$ & $0.365 * *$ & 0.984 & $1.835 * *$ & 1.124 & 0.958 & 0.817 \\
\hline & $\begin{array}{l}\text { More than } 24 \text { months } \\
\text { During at least } 1 \text { year }\end{array}$ & $1.505 * *$ & $0.294 * *$ & $0.334 * *$ & $4.034 * *$ & $0.589 * *$ & $0.446 * *$ & 1.304 \\
\hline \multirow[t]{3}{*}{ Sickness days (ref. $=0$ ) } & $\begin{array}{l}\text { in the past } 10 \text { years } \\
\text { During at least } 1 \text { year }\end{array}$ & $0.603 *$ & 1.378 & 1.627 & $2.055^{* *}$ & $2.349 * *$ & $9.427 * *$ & $2.555^{*}$ \\
\hline & in the past 5 years & 0.917 & $1.409 * *$ & 1.120 & $1.744 * *$ & $2.664 * *$ & $5.215 * *$ & $1.749 *$ \\
\hline & In 2004 & 0.869 & 1.359 & 0.864 & 0.939 & $1.589 *$ & $2.145 * *$ & 1.304 \\
\hline Nagelkerke $\mathrm{R}^{2}$ & 0.241 & & & & & & & \\
\hline $\mathrm{N}$ & 8,926 & & & & & & & \\
\hline
\end{tabular}


Table 5: Multinomial regression model for work-to-retirement trajectories: private sector

\begin{tabular}{|c|c|c|c|c|c|c|c|c|}
\hline & & $\begin{array}{l}\text { Long } \\
\text { career }\end{array}$ & $\begin{array}{l}\text { Early } \\
\text { retirement }\end{array}$ & $\begin{array}{l}\text { Part-time } \\
\text { retirement }\end{array}$ & Unemployment & Disability & Long disability & Death \\
\hline Female (ref. $=$ Male) & & 1.074 & 1.072 & $1.357 * *$ & 1.131 & 0.910 & $0.646^{* *}$ & $0.499 * *$ \\
\hline \multirow[t]{3}{*}{ Marital status (ref. = Married) } & Not married & $1.539 * *$ & 0.937 & 0.694 & 1.154 & 0.963 & 0.998 & 1.180 \\
\hline & Divorced & 1.142 & 0.763 & 0.735 & 0.844 & 1.016 & 1.296 & 1.349 \\
\hline & Widowed & 1.098 & 1.135 & 0.914 & 1.165 & 1.371 & 1.328 & 2.239 \\
\hline Children (ref. $=$ No children) & & 1.147 & 0.990 & 1.112 & 0.861 & 0.927 & 0.937 & 1.001 \\
\hline \multirow[t]{2}{*}{ Education (ref. = Lower) } & Intermediate & 1.199 & 0.872 & 0.941 & 0.879 & 0.835 & 0.838 & 0.804 \\
\hline & Higher & $1.398 *$ & 0.879 & 1.053 & $0.599 * *$ & 0.660 & 0.777 & 0.789 \\
\hline \multirow[t]{2}{*}{$\begin{array}{l}\text { Occupational status } \\
\text { (ref. = Lower-level employees) }\end{array}$} & Upper-level employees & 1.290 & 0.918 & 0.904 & 0.862 & 1.178 & 0.650 & 0.865 \\
\hline & Manual workers & 0.869 & 0.900 & 1.000 & 1.091 & $1.521 * *$ & 1.237 & 0.957 \\
\hline \multirow[t]{3}{*}{ Income (ref. = Lowest quartile) } & Second quartile & 0.976 & 0.637 & $2.131 * *$ & 1.084 & 1.014 & 1.253 & 0.940 \\
\hline & Third quartile & 1.118 & 1.369 & $1.966 * *$ & 1.216 & 0.839 & 1.142 & 0.968 \\
\hline & Highest quartile & 1.040 & $1.957 * *$ & $1.802 * *$ & 1.136 & $0.536 * *$ & 0.755 & 0.549 \\
\hline \multirow[t]{2}{*}{ Months in unemployment (last 10 years) $($ ref. $=0)$} & Less than 24 months & 1.169 & $0.253 * *$ & $0.642 * *$ & 1.069 & 1.213 & 1.182 & 1.008 \\
\hline & $\begin{array}{l}\text { More than } 24 \text { months } \\
\text { During at least } 1 \text { year }\end{array}$ & 1.333 & 0.545 & 0.523 & $2.495 * *$ & 1.031 & 1.515 & $2.356^{* *}$ \\
\hline \multirow[t]{3}{*}{ Sickness days (ref. $=0$ ) } & $\begin{array}{l}\text { in the past } 10 \text { years } \\
\text { During at least } 1 \text { year }\end{array}$ & 0.731 & 0.621 & 1.523 & $1.656^{*}$ & 1.754 & $4.860 * *$ & 1.818 \\
\hline & in the past 5 years & 1.121 & 1.401 & 1.050 & $1.827 * *$ & $2.687 * *$ & $4.184 * *$ & $2.190 * *$ \\
\hline & In 2004 & 0.769 & 1.175 & 1.053 & 1.059 & 1.336 & $2.122 * *$ & 1.015 \\
\hline Nagelkerke $\mathrm{R}^{2}$ & 0.110 & & & & & & & \\
\hline $\mathrm{N}$ & 8,499 & & & & & & & \\
\hline
\end{tabular}

Note: Indicated are odds ratios. Reference category of the dependent variables is 'Standard retirement'. $* \mathrm{p}<0.05, * * \mathrm{p}<0.01$. 
Table 6: Multinomial regression model for work-to-retirement trajectories: public sector

\begin{tabular}{|c|c|c|c|c|c|c|c|c|}
\hline & & $\begin{array}{l}\text { Long } \\
\text { career }\end{array}$ & $\begin{array}{l}\text { Early } \\
\text { retirement }\end{array}$ & $\begin{array}{l}\text { Part-time } \\
\text { retirement }\end{array}$ & Unemployment & Disability & Long disability & Death \\
\hline Female (ref. $=$ Male) & & $0.728 * *$ & $0.570 * *$ & 1.042 & 0.705 & $1.611 * *$ & 1.231 & $0.419 * *$ \\
\hline \multirow[t]{3}{*}{ Marital status (ref. = Married) } & Not married & 0.979 & 0.799 & $0.401 * *$ & 1.032 & 1.088 & 0.888 & 1.957 \\
\hline & Divorced & $1.703 * *$ & 1.116 & 0.749 & 1.001 & $1.417 *$ & 1.017 & 1.071 \\
\hline & Widowed & 1.077 & 0.863 & $0.404 * *$ & $2.213^{*}$ & 1.361 & 0.834 & 0.322 \\
\hline Children (ref. = No children) & & 1.103 & 1.030 & 0.956 & 0.851 & 0.968 & $0.630 *$ & 1.015 \\
\hline \multirow[t]{2}{*}{ Education (ref. = Lower) } & Intermediate & 0.929 & $2.065 * *$ & $1.446^{*}$ & 0.861 & 0.842 & 0.804 & 0.848 \\
\hline & Higher & $2.018 * *$ & $3.412 * *$ & $1.919 *$ & 0.783 & 0.700 & 0.594 & 0.875 \\
\hline \multirow[t]{2}{*}{$\begin{array}{l}\text { Occupational status } \\
\text { (ref. = Lower-level employees) }\end{array}$} & Upper-level employees & $0.716^{*}$ & $0.458 * *$ & 0.763 & 1.007 & $0.601 *$ & 0.747 & 0.574 \\
\hline & Manual workers & 1.026 & $0.524 * *$ & 1.188 & 1.139 & $1.593 * *$ & $2.076 * *$ & 1.388 \\
\hline \multirow[t]{3}{*}{ Income (ref. = Lowest quartile) } & Second quartile & 1.261 & 1.139 & 1.016 & $0.541 * *$ & 1.015 & 0.710 & $0.474 *$ \\
\hline & Third quartile & 1.321 & $1.921 *$ & 0.813 & $0.227 * *$ & 0.818 & 0.803 & 0.669 \\
\hline & Highest quartile & $1.676 * *$ & $2.692 * *$ & 1.021 & $0.225 * *$ & 0.897 & 0.739 & 1.091 \\
\hline \multirow[t]{2}{*}{ Months in unemployment (last 10 years) $($ ref. $=0)$} & Less than 24 months & $1.768 * *$ & $0.118 * *$ & 0.942 & $3.776^{* *}$ & 1.011 & 1.063 & 0.615 \\
\hline & $\begin{array}{l}\text { More than } 24 \text { months } \\
\text { During at least } 1 \text { year }\end{array}$ & $1.407 *$ & $0.093 * *$ & $0.137 * *$ & $9.100 * *$ & $0.402 * *$ & $0.349 * *$ & 1.246 \\
\hline \multirow[t]{3}{*}{ Sickness days (ref. $=0$ ) } & $\begin{array}{l}\text { in the past } 10 \text { years } \\
\text { During at least } 1 \text { year }\end{array}$ & 0.632 & 1.305 & 1.405 & 1.516 & $3.359 * *$ & $11.732 * *$ & $2.764^{*}$ \\
\hline & in the past 5 years & 0.795 & $1.748 * *$ & 1.183 & $1.855^{* *}$ & $3.172 * *$ & $6.143 * *$ & 1.827 \\
\hline & In 2004 & 0.974 & 1.036 & 0.686 & 1.197 & $1.677^{*}$ & $2.250 * *$ & 1.036 \\
\hline Nagelkerke $\mathrm{R}^{2}$ & 0.271 & & & & & & & \\
\hline $\mathrm{N}$ & 5,887 & & & & & & & \\
\hline
\end{tabular}

Note: Indicated are odds ratios. Reference category of the dependent variables is 'Standard retirement'. $* \mathrm{p}<0.05, * * \mathrm{p}<0.01$. 
Annex: Substitution cost matrix for calculating sequence distances

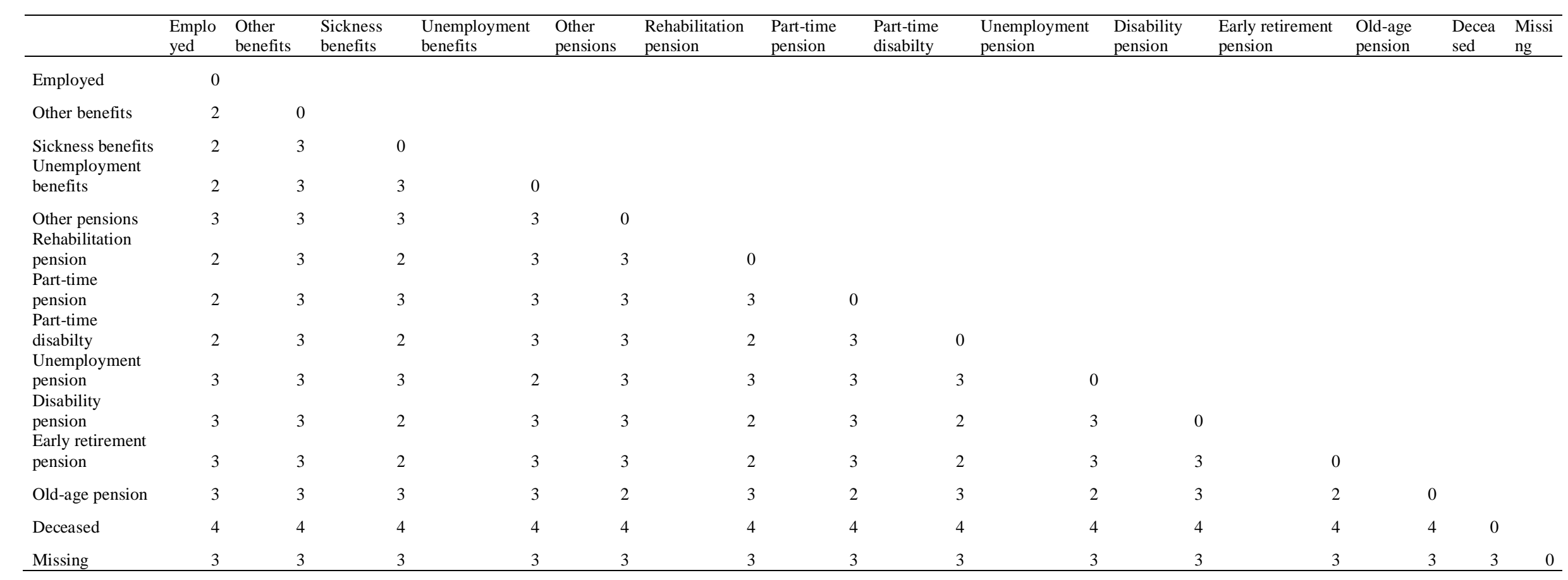

